\title{
Radiological assessment of natural radionuclides in soil within and around crude oil flow and gas compression stations in the Niger Delta, Nigeria
}

\author{
J.A. ADEMOLA ${ }^{1}$, E.E. ATARE ${ }^{1}$
}

(Manuscript received 12 December 2009, accepted 22 February 2010)

ABSTRACT Natural radionuclide concentrations in soil samples collected within and around crude oil flow and gas compression stations in the Niger Delta, Nigeria, were determined using gamma-ray spectroscopy. The mean activity concentrations of ${ }^{40} \mathrm{~K},{ }^{238} \mathrm{U}$ and ${ }^{232}$ Th varied from $30.1 \pm 3.0$ to $59.0 \pm 17.1$, BDL to $8.8 \pm 2.3$ and $7.9 \pm$ 3.7 to $10.9 \pm 1.9 \mathrm{~Bq} \cdot \mathrm{kg}^{-1}$, respectively. The ${ }^{40} \mathrm{~K},{ }^{238} \mathrm{U}$ and ${ }^{232} \mathrm{Th}$ contents of the soil samples are very low compared with the world average for natural background area. The absorbed dose rate and effective dose ranged from 6.9 to $11.1 \mathrm{nGy}^{-1}$ and 8.5 to 13.6 $\mu \mathrm{Sv} . \mathrm{y}^{-1}$, respectively. The annual gonadal dose equivalent rate ranged from 48.9 to $77.5 \mu \mathrm{Sv} . \mathrm{y}^{-1}$, which is lower than the world average of $0.30 \mathrm{mSv} \cdot \mathrm{y}^{-1}$. The radium equivalent activity and the external hazard index of the soil samples were below the recommended limits of $370 \mathrm{~Bq} \cdot \mathrm{kg}^{-1}$ and unity, respectively. The results obtained reveal that there is no significant radiation hazard due to natural radionuclides of the soil samples in the studied areas.

Keywords: Natural radionuclides / radiological assessment / crude oil / Niger delta

RÉSUMÉ Évaluation radiologique de radionucléides naturels dans le sol collectés à l'intérieur et autour des stations de compression des gaz dans le delta du Niger, Nigéria.

Les concentrations en radionucléides naturels dans les échantillons de sol collectés à l'intérieur et autour des stations de compression des gaz et de pompage du pétrole brut dans le delta du Niger, Nigéria ont été déterminées par spectroscopie gamma. Les concentrations moyennes en ${ }^{40} \mathrm{~K},{ }^{238} \mathrm{U}$ et ${ }^{232} \mathrm{Th}$ varient respectivement de $30,1 \pm$ 3,0 à 59,0 $\pm 17,1$, de 0 (valeur inférieure à la limite de détection) à $8,8 \pm 2,3$ et 7,9 \pm 3,7 à $10,9 \pm 1,9 \mathrm{~Bq} \cdot \mathrm{kg}^{-1}$. Le contenu en ${ }^{40} \mathrm{~K},{ }^{238} \mathrm{U}$ et ${ }^{232} \mathrm{Th}$ des échantillons de sol sont très bas par rapport à la valeur moyenne mondiale des zones naturelles. Le débit de dose absorbée et le débit de dose efficace varient respectivement de 6,9 à $11,1 \mathrm{nGy} \cdot \mathrm{h}^{-1}$ et de 8,5 à $13,6 \mu \mathrm{Sv} \cdot \mathrm{y}^{-1}$. Le débit de dose équivalente annuelle aux gonades varie de 48,9 à $77,5 \mu \mathrm{Sv}^{-1} \mathrm{y}^{-1}$ ce qui est inférieur à la moyenne mondiale de $0,30 \mathrm{mSv} \cdot \mathrm{y}^{-1}$. L'activité équivalente en radium et l'indice de risque externe des échantillons de sol étaient en dessous des limites recommandées respectivement de $370 \mathrm{~Bq} \cdot \mathrm{kg}^{-1}$ et l'unité. Les résultats obtenus ont révélé qu'il n'y avait pas de risque radiologique dû aux radionucléides naturels présents dans les échantillons de sol des zones étudiées.

\footnotetext{
1 Department of Physics, University of Ibadan, Ibadan, Nigeria.
} 


\section{Introduction}

The world is naturally radioactive, thereby exposing humans to naturally occurring quantities of radiation on a daily basis. The exposure of human beings to ionizing radiation from natural sources is a continuing and inescapable feature of life on earth. For most individuals, this exposure exceeds that from all man-made sources combined (UNSCEAR, 2000). The exposure arises from natural sources such as cosmic radiation, exposure to radon gas and terrestrial radionuclides. Naturally occurring radioactive materials (NORM) are present in many geological materials and are consequently encountered during geologically-related activities. Many exposures to natural radiation sources are modified by human practices. In particular, natural radionuclides are released to the environment in mineral processing and use, such as phosphate fertilizer production and use and fossil combustion, causing enhanced natural radiation exposures (UNSCEAR, 2000). There are a number of industrial activities that may concentrate radionuclides, particularly members of the ${ }^{232} \mathrm{Th}$ and ${ }^{238} \mathrm{U}$ decay series in products and by-product waste streams. Such activities result in enhanced levels of radiation exposure, referred to as Technologically Enhanced Naturally Occurring Radioactive Materials (TENORM) (Jibiri and Emulue, 2008).

TENORM are naturally occurring radioactive materials, not subject to regulations under the atomic energy act. They are disturbed or altered from natural settings or present in technologically enhanced states due to human activities which may result in a relative increase in radiation exposure and risks to the public above background radiation levels (Egidi, 1999). Industries where TENORM take place include industries directly associated with mining and mineral processing, oil and gas exploration, and production sludges and scales (Tsurikov and Koperski, 1999). Oil and gas production and processing operations have been known to cause NORM to accumulate at elevated concentration in by-product waste streams (Smith et al., 1999).

Otu-Jeremi, Agbarha-Otor and Eruemukohwarien in the Niger delta of Nigeria play host to crude oil flow stations and gas compressor stations. The flow station has pumping and separating equipment (manifold) which is connected by piping from the flow stations directly to the oil wells. The drilled fluid is separated into three fractions - water, gas and crude oil. The crude oil is sent to the storage tanks for onward delivery to the refinery. Large quantities of the gases are flared while others are sent to the compressor stations. Compressor stations pump gas through a pipeline by compressing the gas at intervals along the system. Gas flows by expanding in the pipe from the discharge side (high pressure point) of one station to the suction side (low pressure point) of the next. As gas travels through the pipeline, its pressure drops. The compressor increases the pressure of the gas as it 
moves to the discharge side of the station, enabling the gas to continue its journey. The compressor station also recycles some of the gases back to the oil well to maintain the well pressure. Naturally occurring radioactive materials (radionuclides) present under the ground may, during oil and gas drilling, be enhanced to elevated and harmful levels in the oil and gas extraction equipment. There are also man-made radioactive sources used in improving recovery from oil and gas wells and in detecting leaks in oil and gas pipes. These radioactive sources and the radioactive wastes (arising from man-made and naturally occurring radionuclides) produce ionizing radiations which are harmful to oil and gas workers and members of the general public if not properly handled. Oil and gas production also results in the production of underground water which may contain radium. The radium (if present in produced water), which is a result of changes in pressure, temperature and chemistry at surface conditions, may form a mineral scale on production piping, tanks and separators at the field site. It may also be found in sludge and evaporated deposits in tanks and water on the site (USEPA, 2003). The activities carried out in these communities could contribute to TENORM in the environment.

NORM have the characteristic that owing to the wide distribution, they give rise to a very much larger radiological effect than that caused by the nuclear industry (UNSCEAR, 2000). TENORM sands, gravels and rock, dusts, sludges and other liquids, ash, and scales may contaminate workplaces, wastes, piping and metal or other tanks and containers, storage drums and piles, vent stacks, and disposal sites. Concentrated raw or finished mineral products, including materials in barrels or piles, and metal/ceramic molds (coated with radioactive materials) are also sources of exposure (USEPA, 2003). The TENORM phenomenon in the facilities under study could result in increased radiation exposure and thus it is necessary to evaluate the health risk to the host communities and the staff in these facilities.

\section{Materials and methods}

\subsection{Sample collection and preparation}

Soil samples were collected from crude oil flow and gas compressor stations located in Agbarha-Otor (Eriemu field), Otu-Jeremi (Utorogu field), and Eruemukohwarien in Ughelli North and South Local Government Areas of Delta State, Nigeria. Figure 1 shows the map of the study locations. Fifteen soil samples of about $500 \mathrm{~g}$ were collected from the sites and nineteen samples from the host community at a depth of $15 \mathrm{~cm}$. The samples were kept in polyethylene bags and were properly labeled and taken to the Radiation and Health Physics Research Laboratory, University of Ibadan, for gamma-ray spectroscopy measurements. 


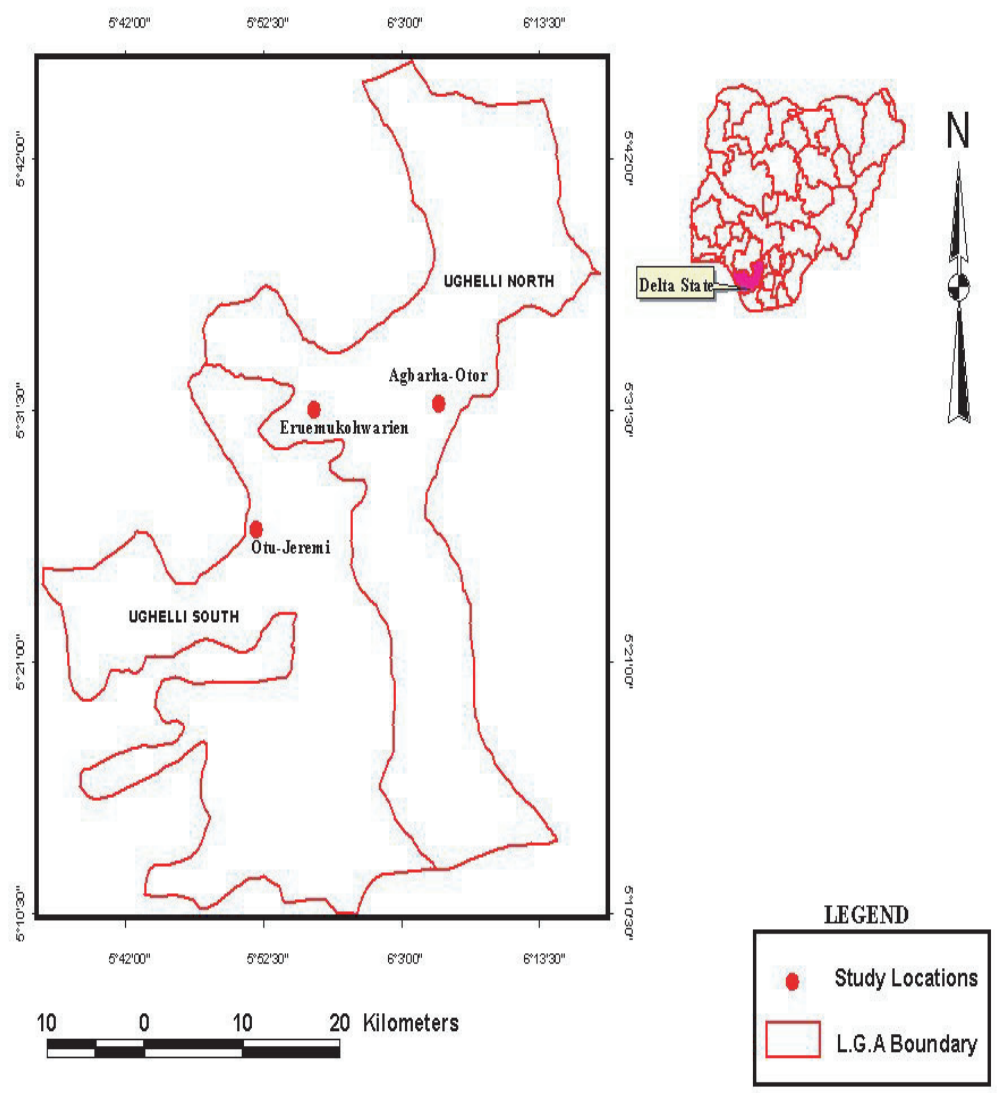

Figure 1 - A map showing study locations.

Carte indiquant la position géographique des sites étudiés.

The soil samples were oven-dried at a temperature of $70{ }^{\circ} \mathrm{C}$ at successive intervals of 20 minutes until a constant weight was obtained, indicating that the samples were free of water. The samples were pulverized and sieved through a $0.2-\mathrm{mm}$ mesh. A mass of $200 \mathrm{~g}$ each was weighed into cylindrical plastic containers of dimensions $6.8 \mathrm{~cm} \times 7.3 \mathrm{~cm}$ and sealed. The sealed samples were kept for more than four weeks to allow for equilibration (secular equilibrium) of Ra-226 and Th-232 with their respective progeny. 


\subsection{Activity concentration measurements}

The detector used for the radioactivity measurements was a lead-shielded $76 \mathrm{~mm} \times$ $76 \mathrm{~mm} \mathrm{NaI}(\mathrm{Tl})$ detector crystal (802 series, Canberra Inc.) coupled to a Canberra series 10 plus multichannel analyzer (MCA) (model number: 1105) through a preamplifier base. The detector has a resolution of about $8 \%$ at energy of $0.662 \mathrm{MeV}\left({ }^{137} \mathrm{Cs}\right)$, which is considered adequate to distinguish the gamma-ray energies of interest in the present study.

The energy calibration of the detector was done using standard radionuclide sources of known gamma energies from Nucleus Inc., Oak Ridge. The efficiency detection calibration of the system was carried out using a reference standard source of known activity prepared from Rocketdyne Laboratories, Canoga Park, California, USA, which is traceable to a mixed standard gamma source by Analytic Inc., Atlanta, Georgia (USA). The activity concentrations of ${ }^{226} \mathrm{Ra}$ and ${ }^{232} \mathrm{Th}$ were determined from the $1.716 \mathrm{MeV}$ photopeak of ${ }^{214} \mathrm{Bi}$ and $2.615 \mathrm{MeV}$ photopeak of ${ }^{208} \mathrm{Tl}$, respectively, while that of ${ }^{40} \mathrm{~K}$ was determined from the $1.460 \mathrm{MeV}$ photopeak following the decay of ${ }^{40} \mathrm{~K}$. Each sample was counted for a period of 36,000 s (10 h). The lower limits of detection (LLD) of ${ }^{226} \mathrm{Ra},{ }^{232} \mathrm{Th}$ and ${ }^{40} \mathrm{~K}$ were determined from the background radiation. This is an estimate for the lowest amount of activity of a specific gamma-emitting radionuclide that can be detected at the time of measurement (IAEA 1989). The LLD obtained are 4.0,4.8 and $17.0 \mathrm{~Bq} \cdot \mathrm{kg}^{-1}$, respectively, for ${ }^{226} \mathrm{Ra},{ }^{232} \mathrm{Th}$ and ${ }^{40} \mathrm{~K}$. Activity concentrations below these values were taken in this study as being below the detection limit (BDL) of the detector.

\section{Results and discussion}

\subsection{Activity concentrations}

The activity concentrations of natural radionuclides of the soil are presented in Table I. In Agbarha-Otor and Eruemukohwarien, there was no accessibility to the gas compression stations. The errors quoted in the mean are standard deviations which depict the variation in activity concentrations. Only activity concentrations greater than the detection limit values of the detector were used for analysis. The activity concentrations of natural radionuclides in the soil samples collected from the three study locations varied from $30.1 \pm 3.0$ to $59.0 \pm 17.1 \mathrm{~Bq} \cdot \mathrm{kg}^{-1}$, BDL to $8.8 \pm 2.3 \mathrm{~Bq} \cdot \mathrm{kg}^{-1}$ and $7.9 \pm 3.7$ to $10.9 \pm 1.9 \mathrm{~Bq} \cdot \mathrm{kg}^{-1}$ for ${ }^{40} \mathrm{~K},{ }^{226} \mathrm{Ra}$ and ${ }^{232} \mathrm{Th}$, respectively. The concentrations of ${ }^{40} \mathrm{~K},{ }^{238} \mathrm{U}$ and ${ }^{232} \mathrm{Th}$ in all the samples collected from the flow stations, gas compression station and the communities in study areas were below the world average, ${ }^{40} \mathrm{~K}: 420,{ }^{238} \mathrm{U}: 33$ and ${ }^{232} \mathrm{Th}: 45 \mathrm{~Bq} \cdot \mathrm{kg}^{-1}$ (UNSCEAR, 2000). 
TABLE I

Activity concentrations of ${ }^{40} \mathrm{~K},{ }^{226} \mathrm{Ra}$ and ${ }^{232} \mathrm{Th}$ in soil samples.

Concentrations en ${ }^{40} \mathrm{~K},{ }^{226} \mathrm{Ra}$ et ${ }^{232} \mathrm{Th}$ dans les échantillons de sol.

\begin{tabular}{lcccccc}
\hline \multirow{2}{*}{ Location } & \multicolumn{2}{c}{${ }^{40} \mathrm{~K}\left(\mathrm{~Bq} \cdot \mathrm{kg}^{-1}\right)$} & \multicolumn{2}{c}{${ }^{226} \mathrm{Ra}\left(\mathrm{Bq} \cdot \mathrm{kg}^{-1}\right)$} & \multicolumn{2}{c}{${ }^{232} \mathrm{Th}\left(\mathrm{Bq} \cdot \mathrm{kg}^{-1}\right)$} \\
\cline { 2 - 7 } & Range & Mean & Range & Mean & Range & Mean \\
\hline Otu-Jeremi & & & & & & \\
Gas compression station (4) & $34.9-72.9$ & $59.0 \pm 17.1$ & $\mathrm{BDL}$ & $\mathrm{BDL}$ & $9.1-12.0$ & $10.0 \pm 1.3$ \\
Flow station (3) & $43.3-61.6$ & $53.5 \pm 9.3$ & $\mathrm{BDL}-4.9$ & $4.9 \pm 1.0$ & $9.4-13.1$ & $10.9 \pm 1.9$ \\
Community (5) & $29.6-79.1$ & $52.3 \pm 18.8$ & $\mathrm{BDL}-7.7$ & $6.5 \pm 1.7$ & $6.6-13.8$ & $8.8 \pm 3.0$ \\
Agbarha-Otor & & & & & & \\
Flow station (5) & $\mathrm{BDL}-50.1$ & $37.2 \pm 9.3$ & $\mathrm{BDL}$ & $\mathrm{BDL}$ & $5.5-11.3$ & $8.9 \pm 3.0$ \\
Community (10) & $\mathrm{BDL}-62.9$ & $38.0 \pm 13.1$ & $\mathrm{BDL}-10.6$ & $8.8 \pm 2.3$ & $\mathrm{BDL}-16.2$ & $7.9 \pm 3.7$ \\
Eruemukohwarien & & & & & & \\
Flow station (3) & $\mathrm{BDL}-32.2$ & $30.1 \pm 3.0$ & $\mathrm{BDL}-4.1$ & $4.1 \pm 0.9$ & $8.8-12.5$ & $10.7 \pm 1.9$ \\
Community (4) & $31.1-100.4$ & $58.0 \pm 31.0$ & $\mathrm{BDL}$ & $\mathrm{BDL}$ & $\mathrm{BDL}-9.5$ & $9.4 \pm 0.1$ \\
\hline BDL dinyyyyyy
\end{tabular}

BDL denotes below detectable limit.

\subsection{Absorbed dose rate in air and effective dose}

The absorbed dose rates, $D\left(\mathrm{nGy}^{-1} \mathrm{~h}^{-1}\right.$ ), in air at $1 \mathrm{~m}$ above ground level were calculated from the mean concentrations of ${ }^{40} \mathrm{~K},{ }^{226} \mathrm{Ra}$ and ${ }^{232} \mathrm{Th}$ in the soil samples using the relation (UNSCEAR, 2000)

$$
D=0.0417 A_{\mathrm{K}}+0.462 A_{\mathrm{Ra}}+0.604 A_{\mathrm{Th}}
$$

where $A_{\mathrm{K}}, A_{\mathrm{Ra}}$ and $A_{\mathrm{Th}}$ are the activity concentrations of ${ }^{40} \mathrm{~K},{ }^{226} \mathrm{Ra}$ and ${ }^{232} \mathrm{Th}$ in Bq. $\mathrm{kg}^{-1}$, respectively. The results of the absorbed dose rates are presented in Table II. The minimum value, $6.9 \mathrm{nGy} \cdot \mathrm{h}^{-1}$, was obtained for the crude oil flow station in Agbarha and the maximum, $11.1 \mathrm{nGy} \cdot \mathrm{h}^{-1}$, for the crude oil flow station in Otu-Jeremi. All the values obtained are less than the world average for background radiation, $60 \mathrm{nGy} \cdot \mathrm{h}^{-1}$, reported by UNSCEAR (2000).

To obtain the effective dose, the absorbed dose rate in air was converted using a conversion factor, $0.7 \mathrm{~Sv} \cdot \mathrm{Gy}^{-1}$, which converts the absorbed dose rate in air into the effective dose in humans and an outdoor occupancy factor of 0.2 . The equation is given as (UNSCEAR, 2000)

$$
E=D \times C \times O \times 8760 \mathrm{~h}
$$

where $E$ is effective dose $\left(\mu \mathrm{Sv} \cdot \mathrm{y}^{-1}\right), D$, absorbed dose rate $\left(\mathrm{nGy} \cdot \mathrm{h}^{-1}\right), C$, conversion factor, $O$ is the occupancy factor and $8760 \mathrm{~h}$ is the annual exposure time. The 


\section{TABLE II}

Absorbed dose rate, effective dose rate, annual gonadal equivalent dose rate, radium equivalent activity and external hazard index of soil samples.

Débit de dose absorbée, débit de dose efficace, débit de dose équivalente aux gonades, activité équivalente en radium et indice de risque externe des échantillons de sol.

\begin{tabular}{lccccc}
\hline Location & Dose $\left(\mathrm{nGy} \cdot \mathrm{h}^{-1}\right)$ & $\begin{array}{c}\text { Effective dose } \\
\left(\mu \mathrm{Sv} \cdot \mathrm{y}^{-1}\right)\end{array}$ & $\mathrm{AGED}\left(\mu \mathrm{Sv} \cdot \mathrm{y}^{-1}\right)$ & $R a_{e q}\left(\mathrm{~Bq} \cdot \mathrm{kg}^{-1}\right)$ & $H_{e x}$ \\
\hline Otu-Jeremi & 8.5 & 10.4 & 60.2 & 18.8 & 0.05 \\
Gas compression station (4) & 11.1 & 13.6 & 77.5 & 24.6 & 0.07 \\
Flow station (3) & 10.5 & 12.9 & 73.3 & 23.1 & 0.06 \\
Community (5) & 6.9 & & & & \\
Agbarha-Otor & 10.2 & 8.5 & 48.9 & 15.6 & 0.04 \\
Flow station (5) & 12.8 & 72.1 & 23.0 & 0.06 \\
Community (10) & 9.6 & 11.8 & 66.8 & 21.7 & 0.06 \\
Eruemukohwarien & 8.1 & 9.9 & 57.5 & 17.9 & 0.05 \\
Flow station (3) & & & & & \\
Community (4) & & & & & \\
\hline
\end{tabular}

results obtained are shown in Table II, with a minimum value of $8.5 \mu \mathrm{Sv}^{-1} \mathrm{y}^{-1}$ to a maximum value of $13.6 \mu \mathrm{Sv} \cdot \mathrm{y}^{-1}$.

\subsection{Annual gonadal equivalent dose}

Organs of interest considered by UNSCEAR (1988) are the gonads, the active bone marrow and the bone surface cells. The annual gonadal equivalent dose (AGED) due to the activity concentrations of ${ }^{40} \mathrm{~K},{ }^{226} \mathrm{Ra}$ and ${ }^{232} \mathrm{Th}$ was calculated using equation (3) (Xinwei et al., 2006; Ademola, 2008a)

$$
\operatorname{AGED}\left(\mu \mathrm{Sv} \cdot \mathrm{y}^{-1}\right)=0.314 A_{\mathrm{K}}+3.09 A_{\mathrm{Ra}}+4.18 A_{\mathrm{Th}}
$$

where $A_{\mathrm{K}}, A_{\mathrm{Ra}}$ and $A_{\mathrm{Th}}$ are the activity concentrations $\left(\mathrm{Bq} \cdot \mathrm{kg}^{-1}\right)$ of ${ }^{40} \mathrm{~K},{ }^{226} \mathrm{Ra}$ and ${ }^{232} \mathrm{Th}$, respectively. The mean activity concentrations of the natural radionuclides were used to calculate AGED and the results are presented in Table II. The AGED obtained for all the soil samples examined in this study varied from 48.9 to $77.5 \mu \mathrm{Sv} . \mathrm{y}^{-1}$. The world average value was calculated using the world average of activity concentrations of soil $\left({ }^{40} \mathrm{~K}: 420 \mathrm{~Bq} \cdot \mathrm{kg}^{-1},{ }^{238} \mathrm{U}: 33 \mathrm{~Bq} \cdot \mathrm{kg}^{-1},{ }^{232} \mathrm{Th}\right.$ : $45 \mathrm{~Bq} \cdot \mathrm{kg}^{-1}$ ) (UNSCEAR, 2000). The result obtained, $421.9 \mu \mathrm{Sv} \cdot \mathrm{y}^{-1}$, shows that those of the present study are less than the world average. 


\subsection{Radium equivalent activity and external hazard index}

In order to examine the suitability of the soil samples for construction purposes, the radium equivalent activity and the external hazard index were determined. This is because the local soil of the areas could be used by the inhabitants for construction of houses.

The naturally occurring radionuclides ${ }^{40} \mathrm{~K},{ }^{226} \mathrm{Ra}$ and ${ }^{232} \mathrm{Th}$ are not evenly distributed in soil and the exposure dose resulting from each differs. To compare the specific activities of building material containing different amounts of ${ }^{40} \mathrm{~K}$, ${ }^{226} \mathrm{Ra}$ and ${ }^{232} \mathrm{Th}$, a common index known as radium equivalent activity, $R a_{e q}$, is used to obtain the weighted sum of the activities. This index is based on the estimation that $1 \mathrm{~Bq} \cdot \mathrm{kg}^{-1}$ of ${ }^{226} \mathrm{Ra}, 0.7 \mathrm{~Bq} \cdot \mathrm{kg}^{-1}$ of ${ }^{232} \mathrm{Th}$ and $13 \mathrm{~Bq} \cdot \mathrm{kg}^{-1}$ of ${ }^{40} \mathrm{~K}$ produce the same gamma-ray dose and is given by (OECD, 1979; Ademola, 2008b)

$$
R a_{e q}=0.077 A_{\mathrm{K}}+A_{\mathrm{Ra}}+1.43 A_{\mathrm{Th}}
$$

where $A_{\mathrm{K}}, A_{\mathrm{Ra}}$ and $A_{\mathrm{Th}}$ are the activity concentrations of ${ }^{226} \mathrm{Ra},{ }^{232} \mathrm{Th}$ and ${ }^{40} \mathrm{~K}$, respectively, in $\mathrm{Bq} \cdot \mathrm{kg}^{-1}$. The $R a_{e q}$ was calculated using the mean activity concentrations of the radionuclides. Table II indicates that the minimum and maximum values are 15.6 and $24.6 \mathrm{~Bq} \cdot \mathrm{kg}^{-1}$, respectively. These values are lower than the recommended value of 370 Bq.kg ${ }^{-1}$ (OECD, 1979; Beretka and Mathew, 1985).

To limit the annual external gamma-ray dose to $1.5 \mathrm{mSv} \cdot \mathrm{y}^{-1}$ (UNSCEAR, 1982), the external hazard index $\left(H_{e x}\right)$ is used. It is given as (Beretka and Mathew, 1985; Ademola, 2008b)

$$
H_{e x}=A_{\mathrm{K}} / 4810+A_{\mathrm{Ra}} / 370+A_{\mathrm{Th}} / 259
$$

where $A_{\mathrm{K}}, A_{\mathrm{Ra}}$ and $A_{\mathrm{Th}}$ and are the activity concentrations of ${ }^{226} \mathrm{Ra},{ }^{232} \mathrm{Th}$ and ${ }^{40} \mathrm{~K}$, respectively, in Bq. $\mathrm{kg}^{-1}$. For the annual effective dose due to radioactivity to be less than or equal to $1.5 \mathrm{mSv} \cdot \mathrm{y}^{-1}$, this index must be less than unity. As shown in Table II, the external hazard indices calculated from the mean activity concentrations of the natural radionuclides are less than unity.

\section{Conclusion}

The natural radioactivity of soil samples collected from the premises of a gas compression station, three crude oil flow stations and around, i.e. within the communities where they are located in three localities in the Niger delta of Nigeria, has been determined. The activity concentrations of ${ }^{40} \mathrm{~K},{ }^{226} \mathrm{Ra}$ and ${ }^{232} \mathrm{Th}$ obtained 
are very low compared with the world average for natural background. The radiological parameters calculated were also low and this shows that there are no significant radiological hazards in the studied area. The study also ascertains the suitability of the soil samples for construction of houses as far as radiation hazard is concerned.

\section{REFERENCES}

Ademola J.A. (2008a) Exposure to high background radiation level in the tin mining area of Jos Plateau, Nigeria, J. Radiol. Prot. 28, 93-99.

Ademola J.A. (2008b) Assessment of natural radionuclide content of cements used in Nigeria, J. Radiol. Prot. 28, 581-588.

Beretka J., Mathew P.J. (1985) Natural radioactivity of Australian building materials, industrial waste and by-products, Health Phys. 48, 87-95.

Egidi P. (1999) Current status of TENORM Regulations and Developing Issues from Federal, State and International Perspectives, Health Physics Society Annual Meeting, Philadelphis, PA, 27 June, PEP course 2-H, Bt.

IAEA (1989) International Atomic Energy Agency. Measurements of Radionuclides in Food and the Environment - A Guidebook. STI/DOC/10/295 IAEA Vienna.

Jibiri N.N., Emelue H.U. (2008) Soil radionuclide concentration and radiological assessment in and around a refining and petrochemical company in Warri, Niger Delta, Nigeria, J. Radiol. Prot. 28, 361-368.

OECD (1979) Organization of Economic Cooperation and Development. Exposure to radiation from natural radioactivity in building materials, Report by a Group of Experts of the OECD (Paris: Nuclear Energy Agency).

Smith K.P., Blunt D.L., Williams G.P., Arnish J.J., Pfingston M., Herbert H., Haffenden R.A. (1999) An assessment of the disposal of petroleum industry NORM in non-hazardous land fills. National Petroleum Technology Office US Department of Energy Report No. DOE/BC/W-31109-ENG-38-8.

Tsurikov N., Koperski J. (1999) TENORM Legislation - Theory and Practice, IAEA TECDOC-1271, Technologically enhanced natural radiation (TENR-II), Proceedings of an International Symposium, Rio de Janeiro, Brazil, September, pp. 3-9.

UNSCEAR (1982) United Nations Scientific Committee on the Effects of Atomic Radiation. Ionizing Radiation: Sources and Biological Effects. 1982 Report to the General Assembly, with scientific annexes. Annex C: Technologically modified exposures to natural radiation (New York, United Nations).

UNSCEAR (1988) United Nations Scientific Committee on the Effects of Atomic Radiation, Sources and Effects of Ionizing Radiation, Report to the General Assembly, 43rd Session (New York, United Nations).

UNSCEAR (2000) United Nations Scientific Committee on the Effects of Atomic Radiation. Sources and Effects of Ionizing Radiation, Vol. 1: Sources, Report to the General Assembly, with scientific annexes, Annex B: Exposures from natural radiation sources (New York, United Nations).

USEPA (2003) United States Environmental Protection Agency. Guidance-Potential for radiation contamination associated with mineral and resource extraction industries. Office of Air and Radiation memorandum, April 15 (Washington DC, 20460).

Xinwei L., Lingqing W., Xiaodan J., Leipeng Y., Gelian D. (2006) Specific activity and hazards of Archeozoic-Cambrian rock samples collected from the Weibei Area of Shaanxi, China, Radiat. Prot. Dosim. 118, 352-358. 